\title{
Obituary for Dr. Ferdinand Ploner
}

\author{
Wolfgang Hilbe
}

Published online: 17 November 2015

(C) Springer-Verlag Wien 2015

It is with deepest regret that we have to inform you about the death of our colleague and friend Dr. Ferdinand Ploner.

Dr. Ploner was an extremely active and supportive member of the Editorial Board of memo. Death claimed him so unexpectedly that we were all deeply shocked. With Dr. Ploner's demise, the team of memo loses an excellent oncologist, an exemplary and popular colleague, who was able to unify empathetic patient treatment, highly qualified training, as well as considerate interdisciplinary cooperation with the utmost medical expertise in his own person.

His helpful nature, characterized by humanity and tolerance made him acquire a high amount of acknowledgement and appreciation wherever he was known.

Dr. Ploner was the author of numerous publications and was a member of national and international medical societies. His death leaves a wide gap as he was a highly qualified member of the medical staff of the University Hospital Graz (Austria) and also a board member and reviewer of memo-we will all miss him from an emotional as well as scientific point of view.

Our thoughts are with him and we want to express our sadness and condolences to his family.

\section{Wolfgang Hilbe}

Editor-in-Chief

Waltraud Radlherr memo secretary

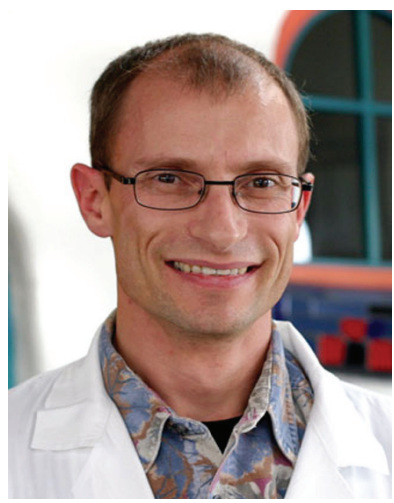

\section{Dr. Ferdinand Ploner}

With great dismay and profound sorrow we deeply regret that our friend and colleague Dr. Ferdinand Ploner suddenly and completely unexpectedly passed away. Ferdinand, you were a brilliant man and a true friend, with a deep passion for practicing medicine. Your death has left a huge void in our lives. We miss you as a friend, we miss you as a colleague, and your patients miss you as an oncologist, who was always able to give them the optimal therapy. Thank you, Ferdinand, for the time we were allowed to spend with you. We offer our sincerest condolences to your partner, Edith, your stepson, Julian, your parents and your sisters, and brother. Ferdinand, we miss you so much.

Thomas Brodowicz

Bernadette Liegl-Atzwanger

Wolfgang Eisterer 